\title{
Fox v. City of Los Angeles: Preference of Religion and the Use of Independent State Constitutional Grounds
}

In Fox v. City of Los Angeles, ${ }^{1}$ the supreme court held that the city's practice of illuminating a Christian cross on city hall to commemorate Christmas and the Latim and Eastern Orthodox Easters constituted a "preference of religion" in violation of article I, section 4 of the California Constitution. ${ }^{2}$ The majority opinion relied exclusively on the California Constitution, apparently on the behef that "current interpretations of the U.S. Constitution may not be as comprehensive."3

This Note argues that while the outcome in Fox was correct, the court's reasoning was too limited. First, the court failed to fornulate a principled and workable definition of "preference of religion." Second, the court should lave adopted a policy of relying first upon the California Constitution in cases involving imdividual liberties.

Part I of this Note summarizes the facts and holding in Fox. Part II analyzes the preference issue and offers a suggcsted definition of "preference of religion." Finally, Part III argues that the court should have adopted a policy of relying first on the California Constitution im individual rights cases, even when the federal constitution would produce the same result.

\section{I}

The CASE

\section{A. Facts}

For thirty years, Los Angeles city officials had authorized a Christmas display of an illuminated cross on city hall. During the past decade, they had also displayed the cross on the Latin and Eastern Orthodox Easters. The plaimtiff objectcd to this practice and sued the city, seeking either to restrain it from lighting the cross or, in the alternative, to obtaim an order requiring the city to light the symbol of any religion on city hall when a member of that religion so requests. ${ }^{4}$ The

1. 22 Cal. 3d 792, 587 P.2d 663, 150 Cal. Rptr. 867 (1978) (Newman, J.) (5-2 decision).

2. Article I, section 4 provides, im pertincnt part: "[f]ree exercise and enjoyment of religion without discrimination or preference are guaranteed."

3. $22 \mathrm{Cal} .3 \mathrm{~d}$ at $796,587 \mathrm{P} .2 \mathrm{~d}$ at $665,150 \mathrm{Cal}$. Rptr. at 869.

4. 22 Cal. 3d at 813,587 P.2d at 676, 150 Cal. Rptr. at 880 (Richardson, J., dissenting). 
trial court issued a preliminary injunction against the display, and the California Supreme Court affirmed.

\section{B. The Court's Opinion}

The supreme court predicated its holding exclusively on article I, section 4 of the California Constitution, which provides that "[f]ree exercise and enjoyment of religion without discrimination or preference are guaranteed." The inotive for this exclusive reliance is unclear. The court may simply have been unsure of the outcome under the U.S. Constitution. ${ }^{5}$

The court concluded that the illumination of the cross on city hall constituted a preference of religion. This judgment appeared to be based solely on the observation that nembers of the Eastern Orthodox faith "apparently thought" there was a preference, since they responded to the illumination of the cross on Latin Easter by requesting and obtaining its illumination on the Orthodox Easter. ${ }^{6}$

The court rejected the possibility that the city could avoid a preference if it displayed the symbols of all faiths, statimg that "[t]he city hall is not an immense bulletin board whereon symbols of all faiths could be thumbtacked or otherwise displayed." The inajority concluded that the illumination of "only the Latin cross . . . does seem preferential when coinparable recognition of other religious syinbols is impracticable." 8

5. The majority did not provide a specific rationale for its sole reliance on the California Constitution. The only reference to the U.S. Constitution came in part II of the opinion, where the court indicated, without further comment, that the U.S. Supreme Court has treated the establishment and free exercise clanses with perplexing diversity of views, and referred to the panoply of views set forth in Wolman v. Walter, 433 U.S. 229 (1977). 22 Cal. 3d at 795, 587 P.2d at 664, 150 Cal. Rptr. at 869.

6. 22 Cal. 3d at 796, 587 P.2d at 665,150 Cal. Rptr. at 869 . The court rejected a claim that the cross was lit to evidence the Easter Seal campaign's symbol rather than the symbol of a Christian religion. The majority noted that the City Council's authorizing unotion referred to Eastern Orthodox Easter, not Easter Seals, and referred to a letter from an Orthodox family thanking the city council "for the acknowledgement shown the Orthodox faith by having the symbol of Christianity, the cross, displayed . . . on the eve of our Easter." Id.

The remainder of the court's discussion of the preference issue consisted of a refutation of the City Attorney's arguments. The court was not persuaded that the lack of protest for thirty years indicated an absence of preference, noting that "there may be coinplex and troubling reasons why" non-Christians had not chosen to object. Id. at 797, 587 P.2d at 666, 150 Cal. Rptr. at 870. The court also rejected the contention that the city was only commemorating the secular aspects of Christunas and Easter, since the city displayed a cross rather than secular objects such as Christinas trees or Easter bunnies. Id. at 798, 587 P.2d at 666, 150 Cal. Rptr. at 870 . Nor did the court accept the claim that the cross was a symbol of peace and good fellowship toward all mankind on an interfaith basis, particularly toward the eastern nations in Europe. The court stated: "[a]ction that effects the display of only a Latin cross does not constitute 'interfaith' recognition. A gesture to 'eastern nations in Europe' hardly demonstrates an interfaith concern for 'all mankind." Id.

7. Id. at 797, 587 P.2d at $665,150 \mathrm{Cal}$. Rptr. at 869 .

8. Id. 
II.

ANALysis of THE PReference IsSUe

\section{A. Fox Failed to Formulate a Desirable Approach to the Preference Issue}

Prior to Fox, the California courts had never defined what state conduct would constitute a prohibited preference of religion. The courts liave considered practices that arguably amounted to a preference of religion, but the decisions in those cases do not turn on an analysis of the preference language of article I, section $4 .^{9}$

One recent appellate decision, Mandel v. Hodges, ${ }^{10}$ does cite the preference language. However, Mandel failed to specifically define preference. The court only held that a governmental proclamation making Good Friday a paid state holiday amounted to "discrimimation' against all non-Christian religions and 'preference' of those which are Christian." "11 Because preference was construed to complement discrimination, the Mandel court failed to consider the possibility that a

9. In California Educ. Facilities Auth. v. Priest, 12 Cal. 3d 593, 526 P.2d 513, 116 Cal. Rptr. 361 (1974), the court upheld the constitutionality of the authority's issuance of reveuue bonds for collegiate academic and dormitory facilities even though some of the revenue could have bencfited sectarian colleges. The court addressed article I, section 4 in general terms, without discussing the possibility of a preference of religion, and concluded that there was no violation because "[t]he Act [providing for the bonds to be issued] is religiously neutral, it neither favors, fosters, nor establishes any religion; nor does it in any way, directly or indirectly, infringe upon free exercise rights." Id. at 603,526 P.2d at 519, 116 Cal. Rptr. at 367.

The supreme court, without referring to the possibility of a preference, upheld a high school district's purchase of copies of the King James Bible for the school library in Evans v. Selma Union High School Dist., 193 Cal. 54, 222 P. 801 (1924). For a more detailed discussion of Evans, see notes 23-29 and accompanying text infra.

In Johnson v. Huntington Beach Union High School Dist., 68 Cal. App. 3d 1, 137 Cal. Rptr. 43 (4th Dist. 1977), the court enjoined the use of public high school facilities for student bible study ineetings. Applying the tripartite test established in Lemon v. Kurtzman, 403 U.S. 602 (1971), the court determined that such a use of the facilities violated both the federal and state establishment clauses. $68 \mathrm{Cal}$. App. 3d at 11-15, $137 \mathrm{Cal}$. Rptr. at 48-51.

In County of Los Angeles v. Hollinger, 221 Cal. App. 2d 154, 34 Cal. Rptr. 387 (2d Dist. 1963), the court struck down a county plan to finance and sponsor a film of a religious parade. The court concluded that this activity, in addition to violating the U.S. Constitution's establislement clanse, was precluded by forner article IV, section 30 of the California Constitution, which prohibited appropriations in aid of any church or sectarian purpose.

The court in Frohlinger v. Richardson, 63 Cal. App. 209, 218 P. 497 (1st Dist. 1923), held that state financing of the restoration of the San Diego Mission, owned by the Roman Catholic Church, violated not only former section 30, but also fonner article IV, sections 22 (which precluded appropriations to institutions that are not under state control) and 31 (which barred gifs of money to individuals, associations, or corporations) of the Califormia Constitution. $63 \mathrm{Cal}$. App. at 217,218 P. at 500 .

10. 54 Cal. App. 3d 596, 127 Cal. Rptr. 244 (1st Dist. 1976).

11. Id. at $617,127 \mathrm{Cal}$. Rptr. at 258 . The court specifically referred to the trial court's finding that "[r]espondents lave failed and refused to grant the same treatment to Petitioner and others similarly situated with regard to Yonı Kippur and other religious holidays of religions other than the Christian religion." Id. at 604, 617, 127 Cal. Rptr. at 249, 258. 
practice that does not discriminate against any religion might nevertheless constitute a preference of rehion.

Fox v. City of Los Angeles presented the court with an opportunity to define the substantive content of the preference language. ${ }^{12}$ Since the plaintiff requested alternative injunctions, ${ }^{13}$ the court had the opportunity to base its decision on article I, section 4's prohibition of discrimination against religion, but instead relied on the preference language of that section to affirm the lower court's injunction. ${ }^{14}$ The court thus seemed to endorse a construction of article $I$, section 4 that goes beyond the prohibition of discriminatory state conduct toward religion. ${ }^{15}$ This interpretation supports a preference restriction that extends to state conduct supporting or proinoting religion even if it does not discriminate against any particular sect or group. ${ }^{16}$ The court's opinion, however, failed to delineate the nature of this preference limitation. Its reasoning reveals that the court has not yet distinguished the prohibition against discrimination from that against preference.

\section{Fox Failed to Establish a Principled Definition of Preference}

The supreine court failed to articulate what standard should be applied when governmental conduct has been challenged as preferential. ${ }^{17}$ The inajority supported its finding of preference only by noting that Eastern Orthodox Christians had demanded recognition of their Easter after the city started to display a cross on the Latin Easter. ${ }^{18}$ This reasoning is inadequate because it allows the question of preference to turn on the subjective opinion of the complaining party rather

12. The need for a workable definition was particularly compelling given the procedural posture of the Fox litigation. The supreme court upheld only a preliminary mjunction againist the display. Thus, a trial on the merits was still possible. 22 Cal. $3 \mathrm{~d}$ at 799 n.1, 587 P.2d at 667 n.1, 150 Cal. Rptr. at 871 n.1 (Bird, C.J., concurring). A workable standard would therefore aid not only future courts and litigants, but also the trial court and parties in Fox itself.

13. See note 4 and accompanying text supra.

14. The court found the alternative "display upon demand" injunction to be inappropriate. Id. at 797, 587 P.2d at 665,150 Cal. Rptr. at 869.

15. In analyzing the language of article $I$, section 4 the court concluded: "[P]reference thus is forbidden even where there is no discrimination." Id. at 796, 587 P.2d at 665, 150 Cal. Rptr. at 869.

16. "Governments must commit themselves to 'a position of neutrality' whenever 'the relationship between man and religion' is affected . . . . To be neutral surely means to honor the beliefs of the silent as well as the vocal minorities." Id. at 798-99, 587 P.2d at 666, 150 Cal. Rptr. at 870 (citation omitted). See also Johnson v. Huntington Beach Union High School Dist., 68 Cal. App. 3d at 10, $137 \mathrm{Cal}$. Rptr. at 47. The court in Johnson concluded that the federal constitution mandates governmental neutrality that neither prefers one rehgion over another, nor advances all religion.

17. Justice Clark complained that the majority opimion failed to state a reason for the decision, and that no attempt was made to define a preference. $22 \mathrm{Cal} .3 \mathrm{~d}$ at 823,587 P.2d at 683,150 Cal. Rptr. at 886 (Clark, J., dissenting).

18. Id. at 796, 587 P.2d at 665,150 Cal. Rptr. at 869 . 
than on objective criteria. ${ }^{19}$

\section{Fox Failed to Distinguish Preference From Discrimination}

The Fox court also failed to distinguish a state practice that is prohibited because it discriminates against a religion from one that is forbidden because it nanifests a preference of religion. The court expressly construed article I, section 4 as forbidding preference even where there is no discrimination. ${ }^{20}$ However, the court's refusal to adopt a non-discriminatory "display on demand" policy was not based on the principle that the display of other religious symbols would also be unconstitutional. The court's reasoning indicated that in cases where comparable represcntation of other religious symbols is practicable, ${ }^{21}$ the display might not constitute a preference of religion. ${ }^{22}$

The court relied on Evans v. Selma Union High School District ${ }^{23}$ to support this practicability standard. ${ }^{24}$ The Evans court permitted the school district to purchase copies of the King James Bible for library reference purposes. In support of its conclusion that the district intended the books to be used for non-sectarian purposes, the court noted that the sacred texts of other religions may already be included in or nay be added to the library collection. ${ }^{25}$

The supreme court distinguished Fox from Evans. The court pointed out that librarians can easily offset a potential for preference but that a city hall is much less tractable than the shelves of a school library. ${ }^{26}$

The Fox court's reliance on Evans is misplaced. Evans did not establish a practicability standard for determining whether state conduct constitutes a preference of religion. Instead, Evans focused on the definition of sectarian. ${ }^{27}$ The fact that the library could contain other

19. The majority opinion did acknowledge that governments must commit themselves to "a position of neutrality" whenever the "relationship between man and religion" is affected. $I d$. at 798, 587 P.2d at 666, $150 \mathrm{Cal}$. Rptr. at 870 . This statement, however, was not made in the context of the preference analysis. It was made only to refute the contention that the cross was symbolic of the Christmas season and as such is not a religious service. Id.

20. See note 15 supra.

21. The court did not define practicability. It appeared to consider practicability to be the physical capability to display the symbols of all religions.

22. The court asserted that the California Constitution contains "no requirement that each religion always be represented." $22 \mathrm{Cal}$. 3d at 797, 587 P.2d at 665, $150 \mathrm{Cal}$. Rptr. at 869 . Under a practicability test the city could continue to display religious symbols in public areas. See note 31 infra.

23. $193 \mathrm{Cal} .54,222$ P. 801 (1924).

24. $22 \mathrm{Cal} .3 \mathrm{~d}$ at $797,587 \mathrm{P} .2 \mathrm{~d}$ at $665-66,150 \mathrm{Cal}$. Rptr. at 869-70.

25. $193 \mathrm{Cal}$. at $60,222 \mathrm{P}$. at 803 .

26. 22 Cal. $3 \mathrm{~d}$ at 797,587 P.2d at 666,150 Cal. Rptr. at 870.

27. The Evans court noted the existence of article I, $\S 4$ of the state constitution, but the opinion only discussed whether Political Code $\$ \S 1607$ (which required boards of education and 
rehigious books went to support the court's argument that the Bible was being used for non-sectarian reference purposes. ${ }^{28}$ The Evans court did not use that fact to support an argument for permitting a sectarian use of the book on the grounds that other religious books could also be put on the library shelves. ${ }^{29}$

\section{B. Fox Should Have Defined Preference In Order to Protect the Separation of Church and State}

The majority's imphication that the cross could be displayed if recognition of otler religious syinbols was practicable does not preserve the separation of church and state guaranteed by the California Constitution. ${ }^{30}$ It would not be difficult to imagine a situation in which the government could display the symbols of all religions. ${ }^{31}$ Even if the symbols of all religions are displayed, however, the fundamental value

school trustees "to exclude from school and school libraries all books, publications, or papers of a sectarian, partisan, or denominational character") and 1672 ("[n]o publication of a sectarian, partisan, or denominational character must be used or distributed in any school, or be made a part of any school library; nor must any sectarian or denominational doctrine be taught therein"), in effect at the time of the Evans decision, precluded use of the Bible as a reference book in the school libraries. $193 \mathrm{Cal}$. at $58,222 \mathrm{P}$. at 801 . The court concluded that for library and reference purposes the Bible was not a book of the class prohibited by the statutes. Id. at 57, 222 P. at 802 .

28. The Evans court noted that if the district purchased the King James Bible and sought to place it on the library slelves to the exclusion of all other versions of the Bible, it might be argued that there was an implied declaration that this version was the only true version. Such conduct would be sectarian. The fact that other religious books were either on the library slelves or could be purcliased for the library indicated that no sucl declaration conld be implied from the district's conduct. 193 Cal. at $60,222 \mathrm{P}$. at 803.

29. The Evans court did not require the school district to purcliase other religious books. The court leld that "either [the King James or the Douai version of the Bible] or both may be purchased for and placed in a public scliool library without violation of the law of this state." Id. (emphasis added).

30. The delegates to the 1849 convention committed Califorina to the fundamental policy of neutrality in matters of religiou. A proposal that the state encourage religion was specifically rejected. The delegates debated the merits of basing California's religion clause on New York's constitution rather than Virgimia's. New York framers carefully considered their language, and opted to use broad terms to guarantee religious freedom. New York also decided to extend the principle of impartiality to all denominations, rather than list certaim religious groups that wonld be protected. This liberal approacl was accepted by the California delegates, and can be contrasted with the Virginia approach. The Virginia Constitution referred to the duty owed the "creator" and adnnonished all men to display "Christian forebearance, love, and charity." The Califorina delegation intentionally chose to base its guarantee of religious freedom on a constitution that was calculated to insure impartiality. See 25 Op. Cal. Att'y Gen. 316 (1955); 22 Cal. 3d at 800,587 P.2d at 667,150 Cal. Rptr. at 871 (Bird, C.J., concurring).

31. A city government might, for example, place a message board next to city liall that could be used for messages of any religious organization. A scliool district could reserve rooms on a high scliool campus for clubs from all religions to meet. Acceptance of these activities slould be held to deny citizens free exercise of religion without preference. Partiality toward those people who choose to have a religion is displayed when the state allows its property to be used for religious purposes. See notes $32-34$ and accompanying text infra. 
of protection of the individual against coercion to accept state "approved" religious beliefs would be undermined.

Any governmental display of any religious symbol is coercive. "When the power, prestige, and financial support of government is placed behind a particular religious belief, the indirect coercive pressure upon . . . minorities to conform to this officially approved belief is plam."32 Such subtle compulsion infrimges the individual's freedom of belief. ${ }^{33}$ The degree of state support is irrelevant; limited and infrequent approval of a religious belief may be as dangerous as constant state support. ${ }^{34}$

The coercive nature of governmental support of religion cannot be avoided by providing equal advantages to all religious groups, since such a policy would have a coercive effect on those who choose not to follow any religion. Therefore, the state must be neutral as between those persons with religious beliefs and those without religious beliefs. A mere guarantee that no particular religion will be favored over any other is not sufficient to insure this neutrality.

A definition of preference of religion that promotes the separation of church and state must protect imdividuals from religious coercion and preserve the voluntary nature of religious belief. ${ }^{35}$ The Fox court should have defined preference in a way that promotes these underlying values.

\section{A Suggested Definition of Preference}

The court should have held that an unconstitutional preference of religion exists whenever a government gives an advantage to or confers a benefit on one or inore religions. This standard, while ensurmg

32. Engel v. Vitale, 370 U.S. 421,431 (1962). "When a city so openly promotes the religious meaning of one religion's holidays, the benefit reaped by that religion and the disadvantage suffered by other religions is obvious. Those persons who do not share those holidays are relegated to the status of outsiders by their own government; those persons who observe those holidays can take pleasure in seeing the symbol of their belief given official sanetion and special status." 22 Cal. 3d at 803, 587 P.2d at 670, 150 Cal. Rptr. at 874 (Bird, C.J., concurring).

33. The court suggested that this kind of pressure may prevent citizens from enforcing their rights: "there may be complex and troubling reasons wliy residents who are non-Christians have cliosen not to seek 'equal recognition and aid, or in the alternative, lodge their objection.' " 32 Cal. 3d at 797, 587 P.2d at 666, 150 Cal. Rptr. at 870 .

34. "II]t is proper to take alarm at the first experiment on our liberties. . . . Who does not see that the same authority which can establisl Christianity, in exelusion of all other Religions, may establisli with the saine ease any particular sect of Christians, im exclusion of all other Seets?" $22 \mathrm{Cal} .3 \mathrm{~d}$ at 804, 587 P.2d at 670, $150 \mathrm{Cal}$. Rptr. at 874 (Bird, C.J., coneurring) (quoting J. MAdison, Memorial and Remonstrance Against Religious Assessments, in 2 WRITINOS oF Madison 183, 185-86 (G. Hunt ed. 1901), as quoted in Engel v. Vitale, 370 U.S. at 436).

35. Ideally, the clurch "gains its vitality from the voluntary adherence of its inembers and desires no state aid in the propagation of its point of view." Paulsen, State Constitutions, State Courts, and First Amendment Freedoms, 4 VAND. L. REv. 620, 635 (1951). 
against preference of religion, would not require the excision of all references to religion. ${ }^{36}$ A government would be able to show that no preference exists by proving that the action in question: 1) is necessary to avoid an unconstitutional discrimination against religion; 2) contains both religious and secular elements and that the government is promoting only the secular elements; or 3) has over time lost its religious meaning and has now acquired a purely secular one.

This standard would insure that government activities or displays could not have a coercive effect on peoples' religious beliefs, since any activity or display found to favor any religion would be unconstitutional. Thus, a government could not avoid a finding of preference by allowing the display of all religious symbols. This standard would produce the correct resnlt in Fox. The display of the cross conferred an advantage to Christian religions. It gave the city laall a church-like appearance. ${ }^{37}$ The benefit was particularly significant because the cross was hit on the three holidays when the spiritual ineaning of the cross is most deeply felt. ${ }^{38}$ The city would not be able to prove that no preference existed. There was no evidence that the display was needed to avoid a discrimination against religion, and the cross is a symbol that has retained a uniquely religious meaning. ${ }^{39}$

A inajor objection to a preference definition that would bar any governmental partiality toward religion is that the insulation of government from all religious symbolism would be impractical. ${ }^{40}$ This argument rests on an appeal to the costs and administrative difficulties in removing all references to religion presently associated with government. Administrative inconvenience, however, should not justify the denial of liberties guaranteed by the California Constitution. ${ }^{41}$ A court should not be able to circunivent a constitutional guarantee by claim-

36. This possibility troubled one dissenting justice in Fox, who complained that the majority's reading of the preference language would require the government to:

delete reference to the Deity in the Preamble to our California Constitution, erase the likeness of George Washington at prayer from our postage stamps, remove the Biblical description of the Creator from the face of the current state telephone directory, strike the expression "In God We Trust" from all of our currency, [and] sandblast the term "Anno Domini" from the very comerstone of the public building in which these opinions are written ....

22 Cal. 3d at 822, 587 P.2d at 682, 150 Cal. Rptr. at 886 (Richardson, J., dissenting).

37. 22 Cal. $3 \mathrm{~d}$ at 809,587 P.2d at 673, 150 Cal. Rptr. at 877 (Bird, C.J., concurring).

38. Id. at $811,587 \mathrm{P.2d}$ at $675,150 \mathrm{Cal}$. Rptr. at 879 (Bird, C.J., concurring).

39. Id. at 809,587 P.2d at 673, 150 Cal. Rptr. at 877 (Bird, C.J., concurring).

40. See note 36 supra.

41. See, eg., People v. City of San Buenaventura, 213 Cal. 637, 639-40, 3 P.2d 3 (1931); People v. California Fish Co., 166 Cal. 576, 587, 138 P. 79 (1913). See also CAL. Const. art. 1, $\S 26$ (formerly art. $1, \S 22$ ): "The provisions of this Constitution are mandatory and prohibitory, unless by express words they are declared to be otherwise." 
ing that protection of that guarantee would be administratively diffcult.

Furthermore, the suggested preference standard would not require the removal of all syinbols possibly connected with religion. A government could rebut an inference of preference in any one of three ways. ${ }^{42}$

First, the government could show that the challenged action is necessary to avoid an unconstitutional discrimination against religion. In State ex rel. Singlemann $v$. Morrison, ${ }^{43}$ for example, the city of New Orleans consented to the erection on public property of a statue comnemorating a canonized nun who had given inuch service to the sick and the poor. ${ }^{44}$ The Louisiana court noted that inany cities honor outstanding citizens with statues and plaques. ${ }^{45}$ In holding that the statue could be erected, the court concluded that the Louisiana Constitution's prohibition of discrimination against any religious faith would be violated if the statue of a noted public figure could not be erected because that person had also been honored by a church. ${ }^{46}$ Since California's constitution also bars discrimination against religion, ${ }^{47}$ an object that has some counection with religion could still be displayed where the display inerely places the object on an equal footing with similar secular objects. ${ }^{48}$

Second, the government could demonstrate that it is depicting only the secular coinponents of objects or events, even though they also have religious coinponents. It inust be clear, however, that the purpose and effect of a display are secular rather than religious. The object or event in question must have a secular side. ${ }^{49}$ The timing of the display must insure that it is the secular aspects that are being commeinorated. ${ }^{50}$

42. See text accompanying note 36 supra.

43. 57 So. $2 d 238$ (La. Ct. App. 1952).

44. Id. at $243-44$.

45. Id. at 242 .

46. Id. at 243.

47. CAL. Const. art. I, $\S 4$.

48. An example of this principle's operation in California can be seen through two hypotheticals involving a state erection of a statue commeinorating Father Junipero Serra. If the statue were included among several statues of great figures in California history, there would be no preference of the Catholic faith because this act would only serve to place significant people who were Catholic on an equal ground with important Californians of other faiths. If the state erected the statue as one of several statues commemorating only Catholic priests, however, the state would be displaying partiality.

49. Christunas is an example of an event with religious meaning that can also have secular components. Allen v. Morton, 495 F.2d 65 (D.C. Cir. 1973); Allen v. Hickel, 424 F.2d 944, 948 (D.C. Cir. 1970).

50. This factor was important in the Oregon Supreme Court's decision to permit the display of a cross as a war ineinorial on public land. Eugene Sand and Gravel, Inc. v. City of Eugene, 276 Or. 1007, 558 P.2d 338 (1976), cert. denied, 434 U.S. 876 (1977). The court noted that the cross was 
The motive for the display must be secular. ${ }^{51}$ And where possible, a plaque explaining the secular purpose of the display should be annexed to the display. 52

Third, the government could show that the object or activity in question has lost its religious significance. Many symbols and phrases, although religious in origin, have ceased to have religious ineanings or have also acquired secular meanings. ${ }^{53}$ Two examples of phrases that have acquired secular meanings are "In God We Trust" and "One Nation Under God." 54 The reference to the divinity in the pledge of allegiance may "merely recognize the historical fact that our Nation was believed to have been founded "under God," "55 and the motto "In God We Trust" has been interwoven "so deeply into the fabric of our civil polity that its present use may well not present that type of involvement

ht on days appropriate for patriotism, such as Memorial Day, rather than simply during religious festivals. Id. at 1010 n.1, 558 P.2d at 340 n.l.

This Note does not contend that under the Eugene Sand and Gravel facts, the California Supreme Court should permit a similar display. The case is merely mentioned as an example of how the court might analyze the timing of a government display in an effort to decide if the display is religious or secular.

51. The court should attempt to determine the real motive of the governing body, rather than simply accepting the government's asserted motive. A good example of such an effort is found in Lowe v. City of Eugene, 254 Or. 518, 463 P.2d 360 (1969), decree set aside due to changed circumstances in Eugene Sand and Gravel, Inc. v. City of Eugene, 276 Or. 1007, 558 P.2d 340 (1976), cert. denied, 434 U.S. 876 (1977). The Oregon court refused to accept the argument that a cross erected on public grounds was intended to be a war memorial rather than a religious symbol. The court noted that the city had never claimed that the cross was a war meinorial until after hitigation began. Instead, the court concluded that the cross was approved because a majority of people in Eugene viewed the display with approval simce it reinforced their religious preference, and that these views were brought to bear upon the city government. 254 Or. at $543-44,463$ P.2d at 362 .

Lowe can be compared with Allen v. Morton, 495 F.2d 65 (D.C. Cir. 1973). The Morton court permittcd the inclusion of a nativity scene on federal parkland as part of a secular display of how Americans cclebrate Christmas. The display included reindeer, Christmas trees, Yule logs, and other traditional aspects of Christmas. The court imdicated that the sponsors of the display were non-sectarian civic organizations promoted by the Washington Board of Trade, which existed to further tourism in the District of Columbia. Therefore, commercial rather than religious motives led to the display. Id. at 72 .

52. One of the reasons for the conclusion that the nativity scene in Morton did not have a substantial religious impact was the presence of explanatory plaques that read:

The National Park Service sponsors the Pageant on the basis that this National Celebration Event is wholly secular in character, purpose, and main effect. The illuminated creche display is intended to be reverential to the rehigious heritage aspect of Christmas, but that display is not meant, and should not be taken, either to promote religious worship, or profane the symbols of any religion.

495 F.2d at 73-74.

53. Abington Township School Dist. v. Schempp, 374 U.S. 203, 303 (1963) (Brennan, J., concurring). See also Paul v. Dade Connty, 202 So. 2d 833, 835 (Fla. Dist. Ct. App. 1967), cert. denied, 390 U.S. 1041 (1968) (the dove, the star, the fish, and three intertwimed rings all once had religious symbolism but now may possess secular meanings).

54. 374 U.S. at 303-04 (Brennan, J., concurring).

55. Id. at 304 . 
which the first amendment prohibits." 56

III.

\section{Analysis of the Use of the California Constitution}

In Fox, the supreme court continued its result-oriented practice of relymg on the California Constitution only after concluding that use of the U.S. Constitution might not bring about the desired result. ${ }^{57}$ Instead, the court should have expressly adopted the practice of looking to the state constitution first whenever a violation of imdividual rights has been alleged. Under such a policy of "independent interpretation," 58 the California courts would always use the California Constitution to decide a case unless the result would contravene protections guaranteed under the U.S. Constitution. ${ }^{59}$

There are several justifications for a doctrine of independent inter-

56. Id. at 303. See also Opinion of the Justices, 228 A.2d 161 (N.H. 1967).

57. Use of the California Constitution to resolve issues of individual rights is not new. See Falk, The State Constitution: A More Than "Adequate" Nonfederal Ground, 61 CALIF. L. REv. 273, 277-80 (1973). Earlier decisions under the California Constitution were not truly independent, however, as "the California courts showed great deference to the U.S. Supreme Court, extrapolating their reasoning from Supreme Court opinions." Note, The New Federalism: Toward a Principled Interpretation of the State Constitution, 29 STAN. L. REv. 297, 301 (1977).

The California Supreine Court first declarcd its right to independently interpret the state constitution in People v. Brisendine, 13 Cal. 3d 528, 531 P.2d 1099, 119 Cal. Rptr. 315 (1975) (providing defendants broader search and seizure protection than is required by the federal constitution). The court has relied on Brisendine to legitimize the independent use of the state constitution in a variety of cases. See, e.g., People v. Pettingill, 21 Cal. 3d 231, 578 P.2d 108, 145 Cal. Rptr. 861 (1978) (providing greater protection against self-incrimination); Serrano v. Priest, 18 Cal. 3d 728, 557 P.2d 929, 135 Cal. Rptr. 345 (1976) (deciding, contrary to the U.S. Supreme Court's decision in San Antonio School Dist. v. Rodriguez, 411 U.S. 1 (1973), that education is a fundainental interest). See also People v. Disbrow, 16 Cal. 3d 101, 545 P.2d 272, 127 Cal. Rptr. 360 (1976); People v. Longwill, 14 Cal. 3d 943, 538 P.2d 753, 123 Cal. Rptr. 297 (1975); People v. Norman, 14 Cal. 3d 929, 538 P.2d 237, 123 Cal. Rptr. 109 (1975).

Decisions such as Brisendine, Serrano, and Pettingill imply that the California Constitution may be interpreted independently in any case. The fact patterns under which independent interpretation has actually been einployed have been limited, however, to situations where U.S. Supreme Court precedent would not produce the outcone the court sought.

58. Independent interpretation of the California Constitution should be based on principled standards. Exainples of such standards can be found in Note, supra note 57, at 318-19, and Howard, State Courts and Constitutional Rights in the Day of the Burger Court, 62 VA. L. Rev. 873, 93539 (1976). The California Supreme Court has shown an ability to develop a principled approach to state constitutional interpretation. In People v. Anderson, 6 Cal. 3d 628, 493 P.2d 880, 100 Cal. Rptr. 152 (1972), for example, the court carefully examined the reasons behind its conclusion that the state constitution's proscription of cruel and unusual punishinent barred the death penalty.

59. If the court were to conclude that no individual right had been violated under the California Constitution, it would also lave to decide whether the federal constitution protected the right asserted. Any reading of a state constitution that affords less protection of individual liberties than is required by the federal constitution cannot prevail. Falk, supra note 57, at 280 n.29. Conversely, when the state court's decision is based on the state constitution and provides more protection of individual liberties than is required under the federal constitution, the U.S. Supreme Court will not review its decision. Id. at 275. 
pretation of the California Constitution. It would enable the California courts to provide, where desired, a more extensive protection of individual rights than is provided by the present practice of relying on the federal constitution. It would also result in inore principled decisionmaking. And finally, the court would be provided with a greater opportunity to nuake well reasoned decisions that critically analyze the policies behind state constitutional provisions.

\section{A. Independent Interpretation of the State Constitution Would Maximize Protection of Individual Rights}

Active judicial protection of personal liberties is an important goal. As Justice Breiman has noted, governments are growing more powerful and pervasive. Thus, there exists in nodern America the necessity of protecting the public from arbitrary action by these governments. ${ }^{60}$ Under many circumstances, the California courts might want to provide a greater protection of individual liberties than would be possible under the U.S. Constitution. Independent interpretation of the state constitution would provide the courts with the opportunity to do so.

Even when existing federal precedent is sufficient to protect the individual right asserted, independent interpretation may be desirable. The U.S. Supreine Court's treatment of constitutional issues tends to change over time. ${ }^{61}$ Thus, there is always the risk that a presently adequate federal guarantee will be interpreted more restrictively in the future. ${ }^{62}$ If, however, the California courts interpret the state constitution to provide the desired level of individual rights even though the present imterpretation of the U.S. Constitution would produce the same result, the risk of a loss of individual liberties due to a retrenchinent by the

60. Brennan, State Constitutions and the Protection of Individual Rights, 90 HARv, L. REv. 489,495 (1977).

It is erroneous to assume that the federal constitution should always set the outer limits of protection of individual rights. U.S. Snpreme Court decisions may purposely fall short of fully protecting personal liberties. For example, the U.S. Supreme Court sometimes assumes that state courts can be trusted to safeguard individual rights and therefore limits its own protective role. $I d$. at 502-03. Honest errors are also possible, and " [m]any low level errors that potentially deny due process or equal protection are corrected within the state court system. . . '" Falk, supra note 59, at 285 (quoting Linde, Without "Due Process": Unconstitutional Law in Oregon, 49 OR. L. REv. 125, 133 (1970). And even when the U.S. Supreme Court provides the maximum protection available nnder the federal constitution, there is the possibility that the California Constitution guarantees more.

61. Such a change is evident in many recent U.S. Supreme Court decisions. As one commentator has noted, the Burger Court is "increasingly willing to lay down its own view of the Constitution, of the judicial process, of the role of the Court as the guardian of individual liberties. In many areas, . . . the difference between where we are today and where we were at the close of the Warren era is marked and inescapable." Howard, supra note 58, at 874.

62. Countryman, Why a State Bill of Rights?, 45 WASH. L. REv. 454, 456 (1970). 
U.S. Supreme Court would be greatly reduced, since the availability of state precedent would provide a firm basis for the continued protection of those rights.

\section{B. Independent Interpretation of the State Constitution Assists Principled California Court Decisionmaking}

When the California Supreme Court bases a decision on a federal precedent protecting a certain right, and the U.S. Supreme Court subsequently cuts back on its protection of that right, the California court is placed in an awkward position. An illustration of this is provided by the situation faced by the California Supreme Court in People $v$. Brisendine. ${ }^{63}$ Prior to Brisendine, the law of search and seizure in Cahfornia was governed by People v. Superior Court (Simon). ${ }^{64}$ Simon was in turn based upon Terry v. Ohio, ${ }^{65}$ a U.S. Supreme Court decision based on the federal constitution. ${ }^{66}$ When the U.S. Supreine Court retreated from the protections afforded in Terry, ${ }^{67}$ the California Supreme Court was forced to rely on the state constitution in order to protect the rights asserted in Brisendine. The Simon court, however, had not mentioned the California Constitution. The Brisendine court was thus without an interpretation of the state constitution upon which to rely.

Cases such as Brisendine, in which the California Supreme Court bases its decisions on the state constitution because the federal guarantee has been eroded, have been criticized by both commentators ${ }^{68}$ and dissenting California justices, ${ }^{69}$ who have coinplained that the court has engaged in unprincipled result-oriented use of the California Constitution rather than well reasoned decisionmaking. The integrity of state court decisionmaking is undermined when decisions appear to be based on a disagreenent with the U.S. Supreme Court's results rather than on an inherent difference between the state and federal constitutions. If the California Supreme Court provided a principled interpretation of the state constitution every time personal liberty violations were alleged, however, an independent body of state constitutional law would develop, thus preventing the problem and appearance of such result-oriented decisionmaking.

63. 13 Cal. 3d 528, 531 P.2d 1099, 119 Cal. Rptr. 315 (1975).

64. 7 Cal. 3d 186, 496 P.2d 1205, 101 Cal. Rptr. 837 (1972).

65. 392 U.S. 1 (1968).

66. Note, supra note 57 , at 311 .

67. United States v. Robinson, 414 U.S. 218 (1973). See Note, supra note 57, at 311.

68. See, e.g., Barrett, Anderson and the Judicial Function, 45 S. CAL. L. Rev. 739 (1972).

69. See, e.g., People v. Ramey, 16 Cal. 3d 263, 277-81, 545 P.2d 1333, 1341-44, 127 Cal. Rptr. 629, 637-40 (1976) (Clark, J., dissenting); People v. Disbrow, 16 Cal. 3d 101, 118-21, 545 P.2d 272, 283-85, 127 Cal. Rptr. 360, $371-73$ (1976) (Richardson, J., dissenting). 


\section{Independent Interpretation Would Enhance Well Reasoned Decisionmaking}

Independent use of the California Constitution would also provide for more carefully considered and reasoned decisions by the California courts. When a state court relies on the federal constitution im adjudicating a claim, the legal principles involved are often assumed to be given. Independent interpretation, however, would force the California court to consider, often for the first time, the policies underlying the provision in question. This should result in better reasoned California decisions.

\section{CONCLUSION}

In Fox v. City of Los Angeles, the California Supreme Court made an ad hoc determination that the illumination of a cross on city hall constituted a preference of religion. The court's explanation of why a preference existed was limited and unpersuasive. Unfortunately, the court's opinion failed to take advantage of two opportunities to further the development of California constitutional law.

The supreme court should not have iniplied that one religion's symbol nay be displayed without preference if recognition of other symbols is practicable. Such a standard undermines the values embodied in the constitutional separation of church and state. Instead, the court should have defined preference to prohibit any governmental partiality toward religion. This definition of preference would properly respect the rights protected by article 1 , section 4 of the California Constitution.

The supreme court should have also established a policy of independently interpreting the California Constitution in all cases involving individual rights. Such a policy would give the court the opportunity to protect individual liberties more extensively than would be possible under the federal constitution, and would result in more principled and better reasoned decisions.

Douglas M. Fraleigh, Jr. *

* B.A. 1977, California State University, Sacramento; J.D. 1980, Boalt Hall School of Law, University of California, Berkeley. 